\title{
KEPUASAN MARITAL SEBAGAI HUBUNGAN DEPRESI PASCA DASAR PATERNAL
}

\section{MARITAL SATISFACTION AS CORRELATES OF PATERNAL POST NATAL DEPRESSION}

\section{Lea Andy Shinta}

Fakultas keperawatan, Universitas Klabat Airmadidi

Email : lea.shintya@gmail.com

\begin{abstract}
ABSTRAK
Pendahuluan: Salah satu masalah yang mungkin terjadi setelah kelahiran bayi untuk ayah adalah depresi pasca kelahiran ayah (PPND), depresi pada ayah baru tidak diakui sebagian karena pengetahuan yang relatif terbatas untuk membahas masalah. Pria cenderung melaporkan bahwa mereka mengalami depresi pada kehamilan dan pascapersalinan. Tujuan: Penelitian ini bertujuan untuk menentukan apakah kepuasan pernikahan mempengaruhi depresi pasca kelahiran ayah. Metode: Penelitian ini menggunakan desain deskriptif-korelasional, di mana dalam data dari 300 responden yang dikumpulkan melalui purposive sampling dianalisis menggunakan statistik deskriptif dan inferensial. Populasi dalam penelitian ini ayah yang anak bungsu tiga sampai enam bulan. Hasil: Responden menikmati kehidupan pernikahan yang memuaskan $(\mathrm{M}=4.42)$ dan depresi post-natal ayah rendah $(\mathrm{M}=2.39)$. Kepuasan pernikahan memiliki hubungan yang signifikan dengan paternal post-natal depression p Nilai $=0,006(<0,05)$. Diskusi: Di sarankan kepada Pendidik perawat untuk melakukan seminar dalam koordinasi dengan konselor keluarga tentang cara memperkuat hubungan perkawinan antara suami dan istri.
\end{abstract}

Kata Kunci: Kepuasan pernikahan, Paternal Post Natal Depression

\begin{abstract}
Introduction: One of the possible problems after the birth of a baby for father is paternal post-natal depression (PPND), depression in new fathers is unrecognized in part because of the relatively limited knowledge to discuss the problem. Men are less likely to report that they are depressed in pregnancy and postpartum. Purpose: This study aimed to determine if marital satisfaction influence paternal post-natal depression. Method: The study uses descriptive-correlational design, where in data from 300 respondents gathered through purposive sampling were analyzed using descriptive and inferential statistics. The population in this study fathers whose youngest child three are to six months old. Results: The respondents enjoy satisfactory married life $(\mathrm{M}=4.42)$ and paternal post-natal depression was low $(\mathrm{M}=2.39)$. Marital satisfaction had a significant relationship with paternal post-natal depression $p$ Value $=0.006(<0.05)$. Discussion: It is suggested to Nurse educators to conduct seminar in coordination with family counselor on how to strength the marital relationship between husband and wife.
\end{abstract}

Key Words: Marital satisfaction, Paternal Post Natal Depression
JURNAL

\section{SKOLASTIK}

KEPERAWATAN

Vol, 4, No. 2

Juli - Desember 2018

ISSN: $2443-0935$

E-ISSN 2443 - 16990 


\section{PENDAHULUAN}

Kelahiran bayi adalah peristiwa yang mengubah hidup tidak hanya bagi ibu tetapi juga bagi ayah. Para ayah merasa bahagia, bangga, gembira, dan terberkati. Namun, dengan tanggung jawab dan pengabdian baru, biaya, dan tugas yang dibawa orangtua dapat juga menyebabkan depresi, kelelahan, dan stres.

Salah satu masalah yang mungkin terjadi setelah kelahiran bayi untuk ayah adalah paternal post-natal depression (PPND). Menurut Pearson (2015), depresi pada ayah baru tidak diakui sebagian karena pengetahuan yang relatif terbatas untuk membahas masalah. Pria jarang menunjukkan emosi mereka. Mereka tidak banyak menangis dan seringkali menyembunyikan perasaan mereka. Selain itu, Hibbert (2016), mengakui bahwa pria cenderung untuk melaporkan bahwa mereka depresi pada kehamilan dan pascapersalinan. Menurut Bogucka dan Nawra (2014) dan Kim and Swain, sebagaimana dikutip dalam Musser, Ahmed, dan Foli (2013), pria berisiko menghadapi situasi ini karena mereka perlu beradaptasi dengan perubahan gaya hidup, fungsi keluarga, peran barunya di keluarga serta untuk mengatasi depresi pascakelahiran atau postpartum paternal. Tingkat depresi pascanatal di antara ayah memuncak dari tiga sampai enam bulan setelah kelahiran, gejala depresi pascanatal yang meliputi perasaan sedih, kurang tertarik, masalah tidur dan rendahnya energi (Mann, 2011).
Di Amerika Serikat, satu dari empat ayah baru menjadi depresi yang berjumlah 3.000 ayah yang menjadi depresi setiap hari (Couternay, 2011; My Sahanan, 2012). Di Australia sekitar 16\% dari semua ibu baru, dan 5\% dari ayah mengalami depresi pascanatal dalam setahun setelah melahirkan (BeyondBlue, 2015). Dewan Penelitian Medis Inggris dan Universitas College London mengklaim bahwa 39\% dari ibu baru dan $21 \%$ ayah baru mengalami episode depresi dengan risiko tertinggi berada di tahun pertama setelah kelahiran (Kemp, 2014). Di Jepang, Nishimura, Fujita, Katsuta, dan Ishihara (2015) melaporkan bahwa $13,6 \%$ dari ayah mengalami depresi pascakelahiran ayah. Sementara itu Cina Barat Laut sekitar $54,1 \%$ ayah yang menderita depresi pasca kelahiran ayah (Zhang et all, 2016).

NCT (2015), MySahana (2011), Panda (2011), Nishimura, Fujita, Katsuta dan Ishihara (2015) menyatakan bahwa kemungkinan penyebab depresi pascanatal di antara pria termasuk menjadi ayah, kurangnya dukungan sosial dan lingkaran teman yang terbatas, kurangnya pendidikan tentang PPND, status sosial ekonomi yang buruk dan kepuasan hubungan perkawinan yang buruk. Rendahnya kepuasan hubungan perkawinan secara signifikan berkorelasi dengan depresi pascapersalinan paternal. Kepuasan pernikahan dapat menjadi tujuan penting dalam melaksanakan intervensi untuk PPND (Musser, Ahmed, \& Foli, 2013).

Selama kehamilan dan kelahiran, untuk ibu dan bayi yang baru lahir adalah fokus perhatian. Banyak kali 
ayah ditinggalkan. Di Indonesia, bayi lahir sekitar 4.880.957 pada tahun 2015 (Kompas, 2016). Namun, tidak ada laporan berapa banyak ayah mengalami depresi pascanatal dan apa yang memengaruhi mereka untuk mengalami fenomena seperti itu. Demikian pula, banyak penyedia layanan kesehatan yang tidak terbiasa dengan semakin banyak bukti yang mendukung bahwa masalah depresi pascanatal juga merupakan masalah laki-laki. Sebagai profesional kesehatan, perawat harus memperhatikan kekhawatiran ini dan faktor-faktor yang mempengaruhi kejadiannya, sehingga penelitian ini.

\section{METODE}

Penelitian ini menggunakan desain korelasi deskriptif untuk menyelidiki dan menggambarkan hubungan kepuasan pernikahan dengan depresi pascanatal ayah. Desain deskriptif bertujuan untuk menggambarkan karakteristik umum responden dalam hal kepuasan pernikahan dan depresi pascanatal ayah di antara populasi. 3 . Hipotesis penelitian ini adalah tidak ada hubungan yang signifikan antara kepuasan pernikahan dan depresi pascanatal paternal.

Sebanyak 300 ayah dipilih melalui metode purposive sampling yang digunakan untuk penelitian. Kriteria inklusi berikut digunakan dalam memilih responden untuk penelitian: ayah usia 18-70 tahun, menikah secara sah, hidup bersama dengan istri mereka, yang anak bungsu berusia 3-6 bulan dengan istri pertama

\section{INSTRUMEN}

Untuk menentukan kepuasan pernikahan responden. Peneliti memodifikasi atau merekonstruksi alat Funk dan Rogge (2001) untuk kepuasan pernikahan. Skala Likert lima poin digunakan untuk mengukur tanggapan responden. Nilai reliabilitas 0,892. Untuk menentukan depresi pascanatal paternal responden. Item dalam kuesioner diadopsi dari Cox, Holden, dan Sagovsky (1987) Edinburgh Postnatal Depression Scale. Skala Likert lima poin digunakan untuk mengukur tanggapan responden. . Nilai reliabilitas 0,838

Analisis untuk mengukur persepsi responden tentang kepuasan pernikahan dan depresi pascaternal pasca paternal menggunakan mean dan standar deviasi. Person-r Correlation: digunakan untuk menghitung hubungan antara kepuasan pernikahan dan depresi pasca melahirkan ayah.

\section{HASIL DAN DISKUSI}

Penelitian ini untuk mengetahui apakah kepuasan pernikahan mempengaruhi depresi pascalahir paternal.

Tabel 1. Tingkat Kepuasan Marital Responden

\begin{tabular}{llll}
\hline & N & $\boldsymbol{r}$ & $\begin{array}{l}\boldsymbol{P} \\
\text { value }\end{array}$ \\
\hline $\begin{array}{l}\text { Kepuasan } \\
\text { Pernikahan }\end{array}$ & 300 & 4.42 & 0.53 \\
\hline
\end{tabular}

Hasilnya menunjukkan bahwa responden menganggap hubungan perkawinan mereka dengan istri masing-masing sebagai kepuasan. Ini karena mereka membuat satu titik 
untuk memutuskan bersama untuk keluarga mereka, menganggap istri sebagai sahabat terbaik mereka, dan merasa nyaman dengan istri di sekitar. Karena mereka menganggap bahwa suami dan istri adalah sebuah tim. Jadi, mereka bekerja sama dengan baik.

Studi lain oleh Mathews (2010) mengungkapkan bahwa kepuasan seksual memiliki bagian penting untuk bermain dalam kepuasan pernikahan. Hubungan perkawinan yang bahagia dan puas melindungi keluarga dan membuatnya lengkap. Dasar dari keluarga yang baik adalah hubungan pernikahan yang baik dan kepuasan antara pasangan. Kepuasan hubungan sangat penting untuk dipertimbangkan di antara orang tua setelah melahirkan karena itu mempengaruhi perilaku mengasuh anak bersama ibu yang positif terhadap bayi muda dan umumnya mempromosikan hasil kesehatan yang positif dalam pasangan hubungan (Mece, 2013).

Terlihat pada tabel 2 mean besar untuk depresi pascanatal paternal dari responden

Tabel 2 Tingkat Depresi Postnatal Paternal dari Responden

\begin{tabular}{llll}
\hline & $\mathrm{N}$ & $r$ & $P$ value \\
\hline Paternal & 300 & 2.39 & 0.86 \\
Depression & & & \\
\hline
\end{tabular}

Tabel 2 mean besar untuk depresi postnatal paternal dari responden adalah 2,39 dan standar deviasi 0,86. Hasil ini berarti bahwa responden mengalami depresi postnatal yang rendah.
Penelitian ini terkait dengan studi yang dilakukan oleh Jahromi, Zare, Koshkaki dan Taghizadeganzadeh (2014) menemukan bahwa enam puluh persen responden dalam kelompok depresi memiliki kepuasan pernikahan yang rendah. Kata lain, enam puluh persen responden memiliki kepuasan pernikahan yang rendah dan menderita depresi. Selain itu, Dekel, Vilchinsky, Liberman, Leibowitz, Khaskia, dan Mosseri (2013) menyatakan dalam penelitian mereka bahwa kepuasan pernikahan yang lebih besar dikaitkan dengan tingkat depresi yang lebih rendah.

Tabel 3 Hubungan antara Kepuasan Pernikahan dan Depresi Pascanatal Paternal

Depresi Pascanatal Paternal

\begin{tabular}{lllll} 
& $\mathrm{N}$ & $r$ & $\begin{array}{l}P \\
\text { value }\end{array}$ & $\mathrm{VI}$ \\
& & & \\
\hline Kepuas & 30 & -.158 & .006 & Sig \\
an & 0 & & & \\
Pernika & & & & \\
jan & & & & \\
\hline
\end{tabular}

Hasilnya menunjukkan bahwa kepuasan pernikahan memiliki hubungan yang lemah dengan depresi pascanatal ayah. Selanjutnya, kepuasan pernikahan memiliki korelasi negatif dengan depresi pascanatal ayah. Ini berarti bahwa kepuasan pernikahan yang lebih tinggi, yang lebih rendah adalah kecenderungan dari pengalaman ayah pasca natal depresi. Dari nilai yang signifikan, peneliti menyimpulkan bahwa ada korelasi yang signifikan secara statistik antara kepuasan pernikahan dan depresi pascanatal paternal. Itu berarti, 
peningkatan atau penurunan dalam perkawinan secara signifikan berhubungan dengan peningkatan atau penurunan depresi pascanatal paternal. Dengan demikian, hipotesis nol yang menyatakan "tidak ada hubungan antara kepuasan perkawinan dan ayah pasca natal depresi" ditolak.

Studi tentang Hoseini, Leili, dan Habibi (2015) menyatakan ada hubungan yang signifikan antara kepuasan pernikahan dan depresi antara pria dan wanita setelah melahirkan. Studi lain oleh Koh, Chui, dan Tang (2014) menemukan bahwa ayah yang melaporkan ketidakpuasan dengan hubungan perkawinan ditemukan memiliki skor yang lebih tinggi dalam Edinburgh Postnatal Depression Scale (EPDS). Khan dan Aftab (2013) menyebutkan bahwa meningkatkan kepuasan pernikahan beberapa pengalaman juga memiliki kontribusi signifikan dalam mengurangi tingkat depresi yang dihadapi pasangan. Berdasarkan hasil ini, hubungan perkawinan yang tidak memuaskan yang ditimbulkan oleh perubahan karena persalinan dikaitkan dengan depresi pasca melahirkan ayah.

\section{HASIL DAN PEMBAHASAN}

Tingkat kepuasan pernikahan responden memiliki rata-rata 4,42 (SD $=0,53)$. Ini berarti bahwa responden memiliki kehidupan pernikahan yang memuaskan. Sementara itu, ayah dari depresi pascanatal ayah rendah dengan rata-rata keseluruhan 2,39 $(\mathrm{SD}=0,86)$. Ini menyiratkan bahwa karena responden puas dengan kehidupan perkawinan dan mereka memiliki pengalaman rendah dengan depresi dan juga menyesuaikan diri dengan kelahiran bayi. Ada hubungan yang signifikan antara kepuasan pernikahan dan depresi pasca melahirkan ayah.

\section{KESIMPULAN}

Perawat pendidik harus menanamkan perawat siswa pentingnya pengajaran kesehatan mengenai perawatan pasca melahirkan ayah. Mereka juga harus membantu perawat siswa untuk menyadari dan mengambil tanggung jawab untuk memberikan informasi tentang depresi pasca melahirkan ayah. Kurikulum keperawatan masa depan harus membahas pelajaran tentang merawat depresi pascanatal paternal akan menghasilkan lulusan yang akan memberikan contoh dan perawatan profesional di komunitas dan tempat kerja.

Meskipun profesi keperawatan yang bekerja di rumah sakit, pemberi perawatan kesehatan menyadari bahwa depresi pascalahir ayah bukan hanya masalah tetapi banyak ayah cenderung mengalami depresi pasca kelahiran ayah. Para ayah yang ingin lebih terlibat dengan anak-anak mereka yang baru lahir merasa menahan diri dengan dukungan dari seorang profesional kesehatan. Ayah harus mendapatkan dukungan khusus seperti yang ibu dapatkan, seperti cenderung menemui dokter mereka untuk konsultasi setelah pasca melahirkan. Setelah melahirkan ibu dan bayi selalu fokus untuk mendapatkan dukungan tetapi ayah meninggalkannya.

\section{DAFTAR PUSTAKA}

Beyond Blue. (2015). New Fathers. Retrieved March 20, 2016, from BeyondBlue: 
https://www.beyondblue.org.au /who-does-it-affect/men/whatcauses-anxiety-and-depressionin-men/new-fathers

Courtenay, W. (2012, June 12). Spotlight on Dads: Part One, Paternal Postnatal Depression. Retrieved June 16, 2016, from Science and Sensibility: https://www.scienceandsensibil ity.org/spotlight-on-dads-partone,-paternal-postnataldepression

Bogucka, W. T., \& Nawra, K. (2014). Paternal Postnatal Depression. Archives of Psychiatry and Psychotherapy, , 61-69.

Hibbert, C. (2016). Postpartum Depression \& Men:he Facts on Paternal Postnatal Depression (PPND). Retrieved June 9, 2016, from Dr. Christina Hibbert:

http://www.drchristinahibbert.c om/postpartum-depressionmen-the-facts-on-paternalpostnatal-depression/

Hoseini, S., Leili, P., \& Habibi, M. (2015). The Relation between Social Support and Marital Satisfaction \& \& Couples Depression after the Birth of the First Child. The International Journal of Indian Psychology, 1-10.

Khan, T. M. (2011). Interventions during pregnancy to lower the chances of postnatal depression among women from the Asian subcontinent. Mental Health Family Medicine, 7-9.

Kompas. (2016, June 26). Data Angka Kelahiran Menjadi Peluang Pasar. Retrieved June 26, 2016, from Harian Kompas: http://bisniskeuangan.kompas.c om/read/2015/06/08/20271422 6/Data.Angka.Kelahiran.Menja di.Peluang.Pasar

Mann, D. (2011, May 18). Depresion Health Center. Retrieved March 13, 2016, from WebMD:

http://www.webmd.com

Mathews, M. (2010, October 1). A Study of Factor Contributing to Marital Satisfaction. Retrieved June 21, 2016, from Uzspace: http://uzspace.uzulu.ac.za/bitstr eam/handle/10530/449/A Study of Factors contributing to marital satisfaction. M. Mathews.pdf?sequence $=$

Musser, A., Ahmed, A., \& Foli, K. (2013). Paternal Postpartum Depression. Journal of Health Pediatric Care, 479-485.

NCT. (2015). Postnatal Depresion in Father. Retrieved March 13, 2016, from NCT 1st 1000 Day New Parents Support: https://www.nct.org.uk/parenti ng/postnatal-depression-dads

Nishimura, N., Fujita, Y., Katsuta, M., \& Ishihara, A. a. (2015). Paternal postnatal depression in Japan: an investigation of correlated factors including 
relationship with a partner.

BMC Pregnancy Childbirth.

Pearson, C. (2015, Augustus 28). Why

Postpartum Depression In

Dads Goes Unrecognized -

And Ignored. Retrieved March

21, 2016, from Hoffpost

Parents:

http://www.huffingtonpost.com

/entry/why-postpartum-

depression-in-dads-goes-

unrecognized-and-

ignored_us_55db279fe4b0a40a

a3ab600e

Jurnal Skolastik Keperawatan | Vol.4, No.2 | Jul - Des 2018 | 31 